\title{
Effect of using germinated fenugreek on the quality of ice milk
}

\author{
*Hayam El Gazzar, *Magda Abd El Aziz and **Waheed. I. A. Nasr \\ *Dairy Chem. Department and **Dairy Technology Department, Animal Production Research Institute, \\ Agric. Research Centre, Dokki, Giza, Egypt.
}

\begin{abstract}
The present work was assessed to study the effect of supplementing ice milk with germinated Fenugreek blended in permeate (GFBP) on its quality. Ice milk mix was supplemented with GFBP at ratios $0,2,4$, and 6 $\%$. Changes in the physical and chemical properties of ice milk were investigated. The results indicated that increasing the ratio of GFBP in ice milk caused a gradual increase in viscosity and overrun, while values of $\mathrm{pH}$, specific gravity, weight per gallon, freezing point and melting resistance were gradually decreased. Also, the supplementation with GFBP raised the total solids, protein, crude fiber, volatile fatty acids and caloric values. Amino acids content showed that ice milk supplemented with GFBP contained most amino acids at higher concentration than the control. Moreover, GFBP highly increased the level of vitamins $\left(\alpha\right.$ - tocopherol, $\mathrm{B}_{3}, \mathrm{~B}_{6}, \mathrm{~B}_{9}$ and $\left.\mathrm{B}_{13}\right)$ and minerals $(\mathrm{Ca}, \mathrm{P}, \mathrm{Fe}, \mathrm{Mg} \& \mathrm{Zn})$ of ice milk compared with the control. Sensory evaluation revealed that ice milk supplemented with GFBP at ratios 2 and $4 \%$ were highly accepted and gained more scores. It could be concluded that using GFBP in making ice milk is a good source for vitamins and minerals which improved the nutritional and functional values of the product.
\end{abstract}

Key words: Ice milk, Germinated Fenugreek, Permeate, Physical properties, Chemical composition, Sensory evaluation.

\section{Introduction}

In recent years there is an increase demand for functional foods including dairy products for their unlimited advantages to human health. Several reports recommended a low overall consumption of fat and in particular high cholesterol butter fat for elderly people (Ibrahim et al., 1994; Giese, 1996). Ice milk is a frozen dairy product with a range of $2-$ $4 \%$ fat content. Its price is lower than ice cream. Food and Administration rules (1994) allowed ice milk to be labeled as low-fat ice cream. Germination Fenugreek (Trigonella foenum graecum) is a good source of nutraceutical ingredients for food applications. It is rich in protein (20 -30\%), crude fiber, vitamins, essential amino acids and minerals. Fenugreek is one of the richest sources of selenium which is among the most important antioxidant micronutrients (Joomla, 2009) and $\alpha$ - tocopherol which is the predominant component found in the Fenugreek lipid antioxidants, and it constituted over $84 \%$ of the total amount of tocopherols. The amount of $\alpha$ - tocopherol in Fenugreek seed lipids ranged from 620 to $910 \mathrm{mg} / \mathrm{Kg}$ lipids (Ciftci and Przyblski, 2011). Fenugreek is known to have hypoglycemic, hypato-protective antioxidant properties and also stimulates lactation in women, (Sharma et al., 1990, Gholamali et al., 2005 and Joomla, 2009). Also, Elmnan et al. (2012) reported that Fenugreek seeds had a significant decrease in triglycerides, LDL and an increase in HDL cholesterol.

Fenugreek is one of the most promising medicinal herbs known from ancient times, having nutritional value too. Its green leaves and seeds are used for multi purpose. $100 \mathrm{~g}$ of seeds provide more than $65 \%$ of dietary fiber due to its high fiber content and it has an ability to change food texture. It is well known for its gum, fiber, alkaloid, flavonoids, saponin and volatile contents in various medicinal applications (Meghwal and Goswami, 2012).

In modern food technology, Fenugreek is used as food stabilizer, adhesive and emulsifying agent due to its fiber, protein and gum contents (Brummer $\boldsymbol{e t}$ al., 2003 and Isikli \& Karababa, 2005).

Germination of Fenugreek improved the protein and starch digestibility and increased the bioavailability of minerals. It had also significant higher contents of total protein and total lysine compared to raw seeds. In vitro starch and protein digestibility and availability of $\mathrm{Ca}, \mathrm{Fe}$ and $\mathrm{Zn}$ were also increased appreciably due to reduction in anti nutrient content (phytic acid and polyphenols) after $48 \mathrm{hr}$. germination (Hooda and Jood, 2003)

Permeate is still viewed as approximately $85 \%$ of total milk UF process used for manufacturing cheese is discarded as permeate. Milk plants in Egypt do not have proper treatment systems for the disposal of permeate and the dumping of permeate constitutes a significant loss of potential food and energy. Its disposal as waste poses serious pollution problems for the surrounding environment. Permeate contains lactose in a water solution with various minerals as well as citrate and soluble nitrogen, and it is one of the only milk by - products that has not been extensively used in the food or health industry (Hegazi et al., 2009).

Cacao-derived foods such as Cacao powders, chocolate and other Cacao-related products are polyphenol-rich foods (Wollgast \& Anklam, 2000). 
Phenolics of Cacao have been reported in many studies as being bio-active compounds especially for their anti-oxidant, antiradical and anti-carcinogenic properties .The consumption of Cacao powder enhances the antioxidant capacity of plasma and decreases the content of lipid oxidation products in human plasma (Wang-Polagranto et al., 2006). Also catechin in Cacao prevents oxidation stress caused by exposure to UV rays and prevents also the hepato-toxicity and nefrotoxicity caused by oxidative damage.

A new study by Desideri et al. (2012) showed that the regular consumption dietary of Cacao flavanols improves co-genitive function in elderly subjects with early memory decline.

Therefore, this study was undertaken to assess the effect of supplementing ice milk with germinated Fenugreek blended in permeate on its quality.

\section{Materials and methods}

\section{Materials:}

Fresh cow milk and milk permeate were obtained from the Dairy Production Unit, Animal Production Res. Inst. Agric. Res. Center. Permeate contained $5.01 \%$ total solids, $4.2 \%$ lactose, $0.24 \%$ protein and $0.56 \%$ ash. Skim milk powder; sucrose and Vanilla were purchased from the local market. Carboxy methyl cellulose (as stabilizer and emulsifier) was obtained from the Pharmaceutical Chemicals Nasr. Co., Abo- Zaabel, Kalubia, Egypt. Fenugreek seeds (Trigonella foenum graecum L.), Cacao powder and Nescafe were purchased from the local market. Cacao contained $84 \%$ total solids, $3 \%$ protein, and $3 \%$ lipid. Nescafe contained $87 \%$ total solids, $12 \%$ protein and $10 \%$ fat was also used.

\section{Methods:}

Germination of Fenugreek seeds:

Hooda and Jood (2003) reported that germination improved the nutritional quality of Fenugreek and reduced bitterness to some extent. Germination was carried out by using dry cleaned Fenugreek seeds in sterile Petri dish lined with wet filter papers for $48 \mathrm{hr}$. at $37{ }^{\circ} \mathrm{C}$, with frequent watering (The sprouts reached $2 \mathrm{~mm}$ ) then rinsed with distilled water, and blended in permeate at rate 1: 2 (W/W). This mixture was stored at $-8{ }^{\circ} \mathrm{C}$ until analysed for $\mathrm{pH}$, total solids, fat, protein, crude fiber and ash (Table 1).

Table 1. Chemical composition of germinated Fenugreek blended in permeate (GFBP)

\begin{tabular}{ll}
\hline Items & GFBP \\
\hline $\mathrm{pH}$ & 5.8 \\
\hline Total solid \% & 16.02 \\
\hline Fat \% & 1.67 \\
\hline Protein \% & 6.60 \\
\hline Carbohydrate \% & 6.39 \\
\hline Crude fiber \% & 2.1 \\
\hline Ash \% & 1.36 \\
\hline
\end{tabular}

\section{Ice milk processing:}

Cow milk was heated to $40{ }^{\circ} \mathrm{C}$ and separated into cream ( $65 \%$ fat) and skim milk by using mechanical separator (Cerezo). The formulation of ice milk mix was $4 \%$ fat, $10.5 \%$ solid not fat, $15 \%$ sucrose, and $0.5 \%$ stabilizer. Treatments of ice milk mixture were prepared. The levels of germinated Fenugreek blended with permeate in the mixture of ice milk were 2,4 and $6 \%$.

Ice milk mixture was homogenized and heated to $80^{\circ} \mathrm{C}$ for $15 \mathrm{~s}$ then cooled to $5^{\circ} \mathrm{C}$ and aged at this temperature for $24 \mathrm{hr}$. The mix was frozen by a batch freezer system (Ice cream freezing machine type IGLC, Italy). The resultant ice milk samples were packaged in plastic cups and stored at $-18^{\circ} \mathrm{C}$ until analysed for physical and chemical properties. Three controls were carried out (first with Vanilla $0.05 \%$, the second with Cacao $2 \%$ and the third with Nescafe 2\%) beside different treatments. All experiments were carried out in triplicate.

\section{Analytical methods:}

pH values of ice milk mix samples were measured by a digital $\mathrm{pH}$ meter (Jenway $3505 \mathrm{pH}$ meter ) .Viscosity of ice milk mix samples of each treatment was measured by using a Brookfield DA $\mathrm{E}$ viscometer in $100 \mathrm{ml}$ ice milk mix at $25^{\circ} \mathrm{C}$. The samples were stirred for one min. before measured. All viscosity values were measured at $50 \mathrm{rpm}$ with spindle $\neq 3$. The values were recorded as centipoises (cP) units.

Specific gravity of ice milk mix and resultant product were measured, Weight per gallon was calculated according to Arbuckle (1986).

Overrun and melting resistance of ice milk were determined according to Marshall and Arbukle (1996).

Total solids, protein, ash and crude fiber were determined according to AOAC method (2007). The fat content of all ice milk samples and GFBP were determined by Rose - Gottlieb method (AOAC, 1991). The total volatile fatty acids were determined as described in the method of Kosikowski (1982). The carbohydrate content was calculated by deference. The caloric value was calculated according to the following equation (FAO/WHO, 1985):

Caloric value $=4$ (protein + carbohydrate $)+9($ fat $)$

Amino acids analysis of ice milk was performed according to Bailey (1967). LC 3000 Amino acid analyzer (Eppendrof - Germany) was used for analysis at the condition: Flow rate is $0.2 \mathrm{ml} / \mathrm{min}$., pressure of buffer from 0 - to 50 bars, pressure of reagent to $0-10$ bars and reaction temperature 123 ${ }^{\circ} \mathrm{C}$.

Evaluation of protein quality of ice milk: Amino acid score $=$ amino acid $(\mathrm{g} / 100 \mathrm{~g})$ of tested protein / amino acid $(\mathrm{g} / 100 \mathrm{~g})$ of reference pattern $\mathrm{x} 100$. The reference protein pattern was of FAO/WHO (1973). 
The water soluble vitamins $\left(B_{3}, B_{6}, B_{9}\right.$ and $\left.B_{13}\right)$ of ice milk were determined according to Ekinci and Kadakal (2005) using HPLC (HPLC Knauer, Germany) at the condition: Kinetex $2.6 \mathrm{u} \mathrm{C}_{18} 100 \mathrm{~A}$, $100 \times 4.6 \mathrm{~mm}$ column. Room temperature, flow rate is $0.5 \mathrm{ml} / \mathrm{min}$. Mobile phase is sodium phosphate buffer (pH 2.8): Methanol (90:10\%). Detection at $254 \mathrm{~nm}, 278 \mathrm{~nm}$ and $358 \mathrm{~nm}$.

Determination of minerals: minerals content of ice milk samples including $(\mathrm{P}, \mathrm{Mg}, \mathrm{Ca}, \mathrm{Fe}, \mathrm{Zn})$ were determined by colorimetric methods according to ElMerzabani et al., (1977) for Phosphorus, Teitz (1983) for Magnesium, Ginder and King (1972) for Calcium, Dreux (1977) for Iron and Hayakawa and Jap (1961) for Zinc.

Sensory evaluation was organoleptically assessed for flavour (50), body and texture (40) and melting quality (10) according to the score card suggested by Kaul and Mathur (1982).

\section{Results and discussion}

Chemical composition of ice milk mixes supplemented with GFBP:

The chemical composition of ice milk mix supplemented with GFBP was recorded in Table (2). The results showed that GFBP increased total solids, protein, fat, carbohydrate and ash in all treatments compared with the controls. The protein contents of ice milk mix supplemented with GFBP at $2-6 \%$ were higher than the control due to protein content in germinated Fenugreek (Hooda and Jood (2003). Also it was found that increasing the ratio of GFBP in ice milk caused proportional increase in the values of crude fiber due to the high content of fiber in Fenugreek (sharma et al., 1990). Soukoulis et al. (2009) explained that, the enrichment of ice cream with dietary fibers is effective way to enhance the nutritional aspects and to promote the rheological and thermal properties of the final product. Fiber helps to lower the rate of glucose absorption in the intestines controlling blood sugar levels (Maghwal and Goswami, 2012). Also, the data showed an increase in T.V.F.A. values with increasing GFBP proportion. These increases were probably due to the high contents of the corresponding constituents of fenugreek as reported in the study by Meghwal and Goswami (2012). As regard to caloric values, fenugreek treatments were higher than the controls. It was clear that supplementing ice milk with germinated Fenugreek blended in permeate improved the chemical characteristics and nutritional quality of the product.

Table 2. Chemical composition of ice milk mixes supplemented with different levels of GFBP

\begin{tabular}{|c|c|c|c|c|c|c|c|c|c|c|c|c|}
\hline \multirow[b]{2}{*}{ Items $\%$} & \multicolumn{4}{|c|}{ Vanilla treatments } & \multicolumn{4}{|c|}{ Cacao treatments } & \multicolumn{4}{|c|}{ Nescafe treatments } \\
\hline & Control & $2 \%$ & $4 \%$ & $6 \%$ & Control & $2 \%$ & $4 \%$ & $6 \%$ & Control & $2 \%$ & $4 \%$ & $6 \%$ \\
\hline $\mathrm{TS}$ & 29.42 & 29.58 & 29.46 & 29.93 & 31.12 & 31.30 & 31.48 & 31.66 & 31.02 & 31.18 & 31.36 & 31.55 \\
\hline Fat & 4.10 & 4.13 & 4.16 & 4.20 & 4.15 & 4.18 & 4.21 & 4.25 & 4.25 & 4.29 & 4.32 & 4.35 \\
\hline Protein & 4.20 & 4.27 & 4.35 & 4.42 & 4.25 & 4.32 & 4.40 & 4.48 & 4.26 & 4.33 & 4.41 & 4.49 \\
\hline Ash & 0.70 & 0.72 & 0.74 & 0.76 & 0.74 & 0.76 & 0.79 & 0.82 & 0.72 & 0.73 & 0.75 & 0.77 \\
\hline $\begin{array}{l}\text { Carbohy- } \\
\text { drate. }\end{array}$ & 20.42 & 20.46 & 20.51 & 20.55 & 21.98 & 22.05 & 22.08 & 22.11 & 21.79 & 21.82 & 21.87 & 21.93 \\
\hline Fiber & 0.01 & 0.05 & 0.10 & 0.15 & 0.26 & 0.30 & 0.35 & 0.41 & 0.25 & 0.30 & 0.34 & 0.40 \\
\hline *T.V.F.A. & 1.75 & 3.25 & 3.75 & 4.25 & 2.25 & 3.75 & 5.50 & 5.75 & 2.00 & 3.50 & 4.25 & 5.50 \\
\hline $\begin{array}{c}\text { Caloric } \\
\text { value } \\
\text { Kcal./100g }\end{array}$ & 135.38 & 136.09 & 136.88 & 137.68 & 142.27 & 143.1 & 143.81 & 144.61 & 142.45 & 143.21 & 144.00 & 144.83 \\
\hline
\end{tabular}

*T.V.F.A. = Total Volatile fatty acids $(\mathrm{ml} 0.1 \mathrm{~N} \mathrm{Na} \mathrm{OH} / 100 \mathrm{~g}$ ice milk mix $)$.

\section{Physical properties of ice milk mixture:}

Data in Table (3) represented the physicochemical characteristics of ice milk mixes supplemented with different levels of GFBP. The $\mathrm{pH}$, specific gravity, and weight per gallon gradually decreased with increasing the level of GFBP, while viscosity of the ice milk mixes showed increasing values as the proportion of GFBP was increased. This was attributed to Fenugreek gum which increased stabilizer concentration (Yousef $\boldsymbol{e t} \boldsymbol{a l}$, 2009). Viscosity depends on stabilizer concentration as reported in the study of El-Etriby (1997).
Furthermore, the data showed decreasing in freezing point with increasing the level of germinated Fenugreek in all treatments. Arbuckle (1986) and Marshal et al. (2003) mentioned that, the freezing point is usually affected by the amounts, type and molecular weight of solutes in the mix. Specific gravity and Wight/gallon of all treatments of ice milk mix supplemented with GFBP were lower than those of the control. 
Table 3. Physical properties of ice milk mixes supplemented with different levels of GFBP.

\begin{tabular}{lcccccccccccc}
\hline \multirow{2}{*}{ Item } & \multicolumn{3}{c}{ Vanilla treatments } & \multicolumn{3}{c}{ Cacao treatments } & \multicolumn{5}{c}{ Nescafe treatments } \\
\cline { 2 - 12 }$y$ & Control & $2 \%$ & $4 \%$ & $6 \%$ & Control & $2 \%$ & $4 \%$ & $6 \%$ & Control & $2 \%$ & $4 \%$ & $6 \%$ \\
\hline $\mathrm{pH}$ & 6.67 & 6.64 & 6.61 & 6.57 & 6.79 & 6.77 & 6.77 & 6.70 & 6.54 & 6.51 & 6.48 & 6.44 \\
\hline $\begin{array}{l}\text { Viscosity } \\
(\mathrm{c} . \mathrm{P})\end{array}$ & 15 & 18 & 22 & 25 & 20 & 24 & 27 & 31 & 21 & 25 & 28 & 32 \\
\hline $\begin{array}{l}\text { Freezing } \\
\text { point }\left({ }^{\circ} \mathrm{C}\right)\end{array}$ & -2.3 & -2.6 & -2.8 & -3.0 & -2.2 & -2.3 & -2.5 & -2.7 & -3.0 & -3.3 & -3.5 & -3.8 \\
\hline $\begin{array}{l}\text { Specific } \\
\text { gravity } \\
\left(\mathrm{gm} / \mathrm{cm}^{3}\right)\end{array}$ & 0.980 & 0.976 & 0.970 & 0.965 & 0.976 & 0.972 & 0.967 & 0.959 & 0.978 & 0.971 & 0.963 & 0.957 \\
\hline $\begin{array}{l}\text { Weight/ } \\
\text { gallon } \\
(\mathrm{Kg})\end{array}$ & 3.710 & 3.695 & 3.672 & 3.653 & 3.69 & 3.680 & 3.661 & 3.631 & 3.703 & 3.676 & 3.646 & 3.623 \\
\hline
\end{tabular}

\section{Physical properties of ice milk supplemented with GFBP:}

The results in Table (4) revealed that the overrun of ice milk supplemented with different ratios $(2,4$ and $6 \%$ ) of GFBP were higher compared to the control treatments. This result may be due to that the germinated Fenugreek contains fiber, protein and gum which increased emulsification level (Brummer et al., 2003 and Isikli \& Karababa, 2005). Boilligor et al. (2000) found noticeable increase in overrun with increasing emulsification level. While, it was observed that the overrun of Cacao and Nescafe ice milk treatments were higher than Vanilla treatments. Melting resistance was determined as weight loss (\%) after 15, 30, 45, 60, 75 and $90 \mathrm{~min}$., and the data were recorded in Table (3). It was noticed that melting resistance of ice milk supplemented with GFBP gradually decreased with increasing the substituted GFBP levels comparing with the controls, this may be attributed to the increasing of the overrun.

Table 4. Physical properties of ice milk supplemented with different levels of GFBP.

\begin{tabular}{|c|c|c|c|c|c|c|c|c|c|c|c|c|}
\hline \multirow{2}{*}{ Property } & \multicolumn{4}{|c|}{ Vanilla treatment } & \multicolumn{4}{|c|}{ Cacao treatment } & \multicolumn{4}{|c|}{ Nescafe treatment } \\
\hline & Control & $2 \%$ & $4 \%$ & $6 \%$ & Control & $2 \%$ & $4 \%$ & $6 \%$ & Control & $2 \%$ & $4 \%$ & $6 \%$ \\
\hline $\begin{array}{l}\text { Specific } \\
\text { gravity } \\
\left(\mathrm{gm} / \mathrm{cm}^{3}\right)\end{array}$ & 0.715 & 0.690 & 0.660 & 0.638 & 0.710 & 0.688 & 0.648 & 0.628 & 0.633 & 0.610 & 0.589 & 0.569 \\
\hline $\begin{array}{l}\text { Weight/ } \\
\text { gallon }(\mathrm{Kg})\end{array}$ & 2.707 & 2.612 & 2.499 & 2.415 & 2.688 & 2.605 & 2.453 & 2.378 & 2.397 & 2.309 & 2.230 & 2.154 \\
\hline Overrun $\%$ & 37.14 & 41.40 & 46.12 & 51.81 & 39.87 & 42.92 & 48.80 & 54.10 & 53.70 & 58.10 & 63.50 & 69.30 \\
\hline $\begin{array}{l}\text { Melting } \\
\text { resistance } \\
\text { as loss \% } \\
\text { after: } \\
15 \text { min }\end{array}$ & & & & & & & & & & & & \\
\hline$\frac{15 \mathrm{~min} .}{30 \mathrm{~min} .}$ & $\begin{array}{c}7.57 \\
18.60\end{array}$ & $\frac{11.8}{22.27}$ & $\frac{12.55}{38.50}$ & $\frac{19.57}{46.13}$ & $\frac{9.57}{26.13}$ & $\begin{array}{l}13.35 \\
51.87\end{array}$ & $\frac{16.04}{64.35}$ & $\begin{array}{l}19.86 \\
68.26\end{array}$ & $\begin{array}{l}25.13 \\
68.16\end{array}$ & $\frac{29.20}{72.80}$ & $\frac{31.52}{75.41}$ & $\begin{array}{l}34.31 \\
79.80\end{array}$ \\
\hline $45 \mathrm{~min}$. & 35.81 & 39.33 & 55.21 & 66.63 & 56.63 & 73.43 & 85.21 & 88.90 & 90.80 & 94.60 & 97.31 & 97.20 \\
\hline $60 \mathrm{~min}$. & 53.72 & 63.33 & 73.45 & 84.33 & 74.33 & 90.23 & 99.10 & 99.90 & 97.55 & 100.00 & 100.00 & 100.00 \\
\hline $75 \mathrm{~min}$. & 72.92 & 80.19 & 86.13 & 88.73 & 88.73 & 100 & 100 & 100 & 100 & - & - & - \\
\hline $90 \mathrm{~min}$. & 89.83 & 96.22 & 100 & 100 & 100 & - & - & - & - & - & - & - \\
\hline
\end{tabular}

\section{Amino acids content in ice milk:}

Nutritional protein quality of ice milk was evaluated according to the content of amino acids and compared with reference protein pattern of FAO/WHO. Table (5-1) indicated that the amount of amino acids content in ice milk of different treatments exceeded than the control (EAAs and NEAAs)) with exception of lysine, histidine, alanine, valine and proline. EAAs are important factors in tissue growth. Also, it was noticed that Cacao ice milk treatments contained higher level of essential amino acids except lysine compared to vanilla treatments. Whereas, adding Nescafe to ice milk decreased some essential amino acids such as Isoleucine, Leucine, lysine and valine, while increased methionine, phenylalanine and threonine compared to Vanilla treatments. 
Table 5 1. Amino acids content (g/100g protein) in ice milk supplemented with different levels of GFBP

\begin{tabular}{|c|c|c|c|c|c|c|c|c|c|c|c|c|}
\hline \multirow{2}{*}{$\begin{array}{l}\text { Amino } \\
\text { Acids }\end{array}$} & \multicolumn{4}{|c|}{ Vanilla treatments } & \multicolumn{4}{|c|}{ Cacao treatments } & \multicolumn{4}{|c|}{ Nescafe treatments } \\
\hline & Control & $2 \%$ & $4 \%$ & $6 \%$ & Control & $2 \%$ & $4 \%$ & $6 \%$ & Control & $2 \%$ & $4 \%$ & $6 \%$ \\
\hline \multicolumn{13}{|l|}{ *EAAs: } \\
\hline$\overline{\text { Isoleucine }}$ & 1.80 & 1.80 & 1.82 & 1.83 & 2.09 & 2.10 & 2.11 & 2.12 & 1.43 & 1.48 & 1.55 & 1.6 \\
\hline Leucine & 4.74 & 4.90 & 5.06 & $5 / 23$ & 7.43 & 7.43 & 7.43 & 7.43 & 4.18 & 4.34 & 4.51 & 4.66 \\
\hline Lysine & 7.93 & 7.73 & 7.47 & 7.27 & 5.22 & 5.07 & 4.93 & 4.75 & 3.47 & 3.35 & 3.22 & 3.10 \\
\hline Methionine & 0.97 & 1.48 & 1.98 & 2.47 & 3.88 & 4.33 & 4.80 & 5.16 & 1.46 & 1.89 & 2.36 & 2.85 \\
\hline Phenylalanine & 4.31 & 5.18 & 6.02 & 6.88 & 6.87 & 7.70 & 8.57 & 9.42 & 6.85 & 7.67 & 8.46 & 9.20 \\
\hline Threonine & 1.67 & 2.27 & 2.87 & 3.42 & 2.89 & 3.43 & 3.91 & 4.35 & 1.71 & 2.29 & 2.83 & 3.39 \\
\hline Valine & 1.38 & 1.36 & 1.33 & 1.31 & $2 . .12$ & 2.08 & 2.05 & 2.01 & 0.77 & 0.76 & 0.75 & 0.74 \\
\hline \multicolumn{13}{|l|}{ **NEAAs: } \\
\hline Alanine & 3.17 & 2.62 & 2.53 & 2.15 & 3.27 & 3.26 & 3.25 & 3.24 & 2.14 & 1.87 & 1.59 & 1.29 \\
\hline Arginine & 2.31 & 2.65 & 2.94 & 3.28 & 2.87 & 3.19 & 3.50 & 3.82 & 1.55 & 1.87 & 2.24 & 2.49 \\
\hline Aspartic acid & 3.71 & 4.05 & 4.37 & 4.71 & 6.47 & 6.71 & 6.96 & 7.19 & 4.84 & 5.15 & 5.40 & 5.66 \\
\hline Glutamic acid & 7.64 & 8.06 & 8.41 & 8.80 & 4.87 & 5.30 & 5.68 & 6.07 & 8.59 & 8.92 & 9.25 & 9.56 \\
\hline Glycine & 0.64 & 0.63 & 0.64 & 0.63 & 0.80 & 0.78 & 0.77 & 0.76 & 0.40 & 0.39 & 0.39 & 0.40 \\
\hline Histidine & 12.60 & 9.34 & 6.35 & 3.05 & 8.89 & 5.74 & 3.09 & 0.36 & 8.00 & 5.08 & 2.72 & 0.11 \\
\hline Serine & 1.63 & 1.83 & 1.95 & 2.06 & 2.56 & 2.57 & 2.57 & 2.59 & 2.02 & 2.06 & 2.09 & 2.09 \\
\hline Tyrosine & 7.10 & 7.17 & 7.43 & 7.94 & 9.18 & 9.44 & 9.66 & 9.89 & 7.56 & 7.85 & 8.12 & 8.33 \\
\hline Proline & 10.07 & 7.63 & 5.26 & 2.96 & 4.35 & 2.2 & 0.11 & - & 10.23 & 7.81 & 5.44 & 3.14 \\
\hline
\end{tabular}

*EAAs $=$ essential amino acids, $* *$ NEAAs $=$ non essential amino acids

Table (5-2) showed the essential amino acids content of different treatments in comparison with the reference protein pattern of FAO/WHO; it was observed that the most EAAs score increased in ice milk supplemented with GFBP. The values were higher than $100 \%$ in lysine in case of Vanilla treatments at the different levels of GFBP. The phenylalanine score increased over $100 \%$ in treatment of $6 \%$ GFBP, also threonine increased in treatments of 4 and $6 \%$. Most of EAAs scores in Cacao ice milk treatments were over $100 \%$ with exception of Isoleucine, lysine and valine. While, only phenylalanine score in Nescafe treatments was over $100 \%$ at different ratios of GFBP.

Table 5-2. Amino acids scores of ice milk supplemented with different levels of GFBP compared to references pattern of $\mathrm{FAO} / \mathrm{WHO}$.

\begin{tabular}{|c|c|c|c|c|c|c|c|c|c|c|c|c|c|}
\hline \multirow[b]{2}{*}{$\begin{array}{l}\text { EAAs } g / 100 \mathrm{~g} \\
\text { protein }\end{array}$} & \multicolumn{4}{|c|}{ Vanilla treatments } & \multicolumn{4}{|c|}{ Cacao treatments } & \multicolumn{4}{|c|}{ Nescafe treatments } & \multirow[b]{2}{*}{$\begin{array}{l}\mathrm{FAO} / \\
\mathrm{WHO}\end{array}$} \\
\hline & Control & $2 \%$ & $4 \%$ & $6 \%$ & Control & $2 \%$ & $4 \%$ & $6 \%$ & Control & $2 \%$ & $4 \%$ & $6 \%$ & \\
\hline Isoleucine & 64 & 64 & 65 & 65 & 75 & 75 & 73 & 76 & 51 & 53 & 55 & 57 & 2.8 \\
\hline Leucine & 72 & 74 & 77 & 79 & 112 & 112 & 112 & 112 & 63 & 66 & 68 & 71 & 6.61 \\
\hline Lysine & 137 & 133 & 129 & 125 & 90 & 87 & 85 & 82 & 60 & 58 & 56 & 53 & 5.8 \\
\hline Methionine & 29 & 44 & 58 & 73 & 114 & 127 & 141 & 152 & 43 & 56 & 69 & 84 & 3.4 \\
\hline Phenylalanine & 68 & 82 & 96 & 102 & 109 & 122 & 136 & 150 & 109 & 122 & 134 & 146 & 6.3 \\
\hline Threonine & 70 & 95 & 120 & 143 & 120 & 143 & 163 & 181 & 71 & 95 & 118 & 141 & 2.4 \\
\hline Valine & 39 & 39 & 38 & 37 & 61 & 59 & 59 & 57 & 22 & 22 & 21 & 21 & 3.5 \\
\hline
\end{tabular}

\section{Some vitamins content in ice milk supplemented with GFBP:}

Table (6) represented $\alpha$-tocopherol, vitamins $\mathrm{B}_{3}$ (Niacin), $\mathrm{B}_{6}$ (Pyridoxine), $\mathrm{B}_{9}$ (Folate) and $\mathrm{B}_{13}$ (Oratic acid) in ice milk control and treatments. The results showed that supplementing with GFBP highly increased $\alpha$-tocopherol in Vanilla and Cacao ice milk treatments. That was due to high level of $\alpha-$ tocopherol in Fenugreek (Ciftci and Przyblski, 2011). It has been claimed that $\alpha$-tocopherol protects cell membranes from oxidation by transferring lipid radicals into unreactive compounds (Seppanen et al., 2010). However, it was noticed that $\alpha$ - tocopherol content in Cacao ice milk treatments was lower than Vanilla treatments and not detected in Nescafe treatments. This may be due to constituents in Cacao and Nescafe which interferes or interacts with $\alpha$-tocopherol.

This need more detail studies to demonstrate the effect of Cacao and Nescafe additive on the vitamins content of ice milk. Also, the data revealed that the content of vitamins $\mathrm{B}_{3}, \mathrm{~B}_{6}$, and $\mathrm{B}_{13}$ highly increased, while the content of $\mathrm{B}_{9}$ considerably increased in ice milk supplemented with GFBP for all treatments compared to the controls. This effect attributed to that Fenugreek seeds which is rich in vitamins (Srinivasan, 2006).

Moreover, Leela and Shafeekh (2008) reported that germinated fenugreek contain high level of vitamin $\mathrm{B}_{6}$. As vitamins play an important role in promoting the health of the nervous system (Ball, 
2006). Recently, Doshi et al. (2012) indicated that vitamins (Folate) and minerals (Iron) in Fenugreek help to prevent and cure anemia and maintain good health life for longer duration.

Table 6. $\alpha$-Tocopherol and some water soluble vitamins content $(\mu \mathrm{g} / 100 \mathrm{~g})$ of ice milk supplemented with different levels of GFBP.

\begin{tabular}{|c|c|c|c|c|c|c|c|c|c|c|c|c|}
\hline \multirow{2}{*}{ Vitamins } & \multicolumn{4}{|c|}{ Vanilla treatments } & \multicolumn{4}{|c|}{ Cacao treatments } & \multicolumn{4}{|c|}{ Nescafe treatments } \\
\hline & Control & $2 \%$ & $4 \%$ & $6 \%$ & Control & $2 \%$ & $4 \%$ & $6 \%$ & Control & $2 \%$ & $4 \%$ & $6 \%$ \\
\hline $\begin{array}{l}\alpha- \\
\text { Tocopherol }\end{array}$ & 20 & 30 & 40 & 50 & 11 & 21 & 31 & 41 & - & - & - & - \\
\hline $\mathrm{B}_{3}$ & 220 & 316 & 413 & 510 & 220 & 316 & 414 & 510 & 218 & 298 & 388 & 476 \\
\hline $\mathrm{B}_{6}$ & 170 & 285 & 403 & 520 & 169 & 284 & 402 & 519 & 165 & 255 & 360 & 471 \\
\hline $\mathrm{B}_{9}$ & 14 & 16 & 18 & 20 & 14 & 16 & 18 & 21 & 13 & 14 & 16 & 18 \\
\hline $\mathrm{B}_{13}$ & 720 & 915 & 1101 & 1306 & 700 & 910 & 1088 & 1209 & 691 & 888 & 1080 & 1191 \\
\hline
\end{tabular}

\section{Minerals content:}

The results obtained revealed that the enrichment of ice milk with GFBP increased minerals including $\mathrm{Ca}$, $\mathrm{P}, \mathrm{Mg}, \mathrm{Zn}$ and Fe (Table 7) as Fenugreek is a rich source of calcium and phosphorous following by magnesium, zinc and iron (Basch et al., 2003). Additionally, germination of Fenugreek increased $\mathrm{Ca}, \mathrm{Fe}$, and zinc (Hooda and Jood 2003). Also, milk permeate is a good source for $\mathrm{Ca}, \mathrm{Mg}$, and $\mathrm{P}$
(Hattem et al., 2011). Nasri and Tinay (2007) reported that Fenugreek contains high amount of phosphorus. The present results are in agreement with El Atawy et al. (2001) who found that the addition of Fenugreek to yoghurt increased the level of $\mathrm{Ca}, \mathrm{P}$ and $\mathrm{Fe}$. Also, the data are in line with the study of Jani et al., (2009) who reported high occurrence of $\mathrm{Ca}, \mathrm{Fe}$ and zinc in curry made from Fenugreek.

Table 7. Minerals content $(\mathrm{mg} / 100 \mathrm{~g})$ of ice milk supplement with different levels of GFBP.

\begin{tabular}{|c|c|c|c|c|c|c|c|c|c|c|c|c|}
\hline \multirow{2}{*}{ Minerals } & \multicolumn{4}{|c|}{ Vanilla treatment } & \multicolumn{4}{|c|}{ Cacao treatment } & \multicolumn{4}{|c|}{ Nescafe treatment } \\
\hline & Control & $2 \%$ & $4 \%$ & $6 \%$ & Control & $2 \%$ & $4 \%$ & $6 \%$ & Control & $2 \%$ & $4 \%$ & $6 \%$ \\
\hline $\mathrm{Ca}$ & 94.60 & 98.23 & 101.85 & 105.45 & 87.36 & 91.00 & 94.33 & 97.67 & 76.52 & 80.12 & 83.76 & 87.00 \\
\hline $\mathrm{P}$ & 86.31 & 89.50 & 92.70 & 95.90 & 90.21 & 93.29 & 96.00 & 100.00 & 84.42 & 87.20 & 90.89 & 93.61 \\
\hline $\mathrm{Mg}$ & 16.65 & 17.32 & 18.00 & 18.66 & 17.21 & 17.93 & 18.66 & 19.38 & 17.73 & 18.43 & 19.13 & 19.82 \\
\hline $\mathrm{Zn}$ & 0.36 & 0.39 & 0.42 & 0.46 & 0.40 & 0.44 & 0.47 & 0.51 & 0.45 & 0.49 & 0.51 & 0.55 \\
\hline $\mathrm{Fe}$ & 0.07 & 0.12 & 0.18 & 0.25 & 0.04 & 0.10 & 0.15 & 0.21 & 0.05 & 0.11 & 0.16 & 0.23 \\
\hline
\end{tabular}

\section{Sensory evaluation:}

Table (8) represented the sensory evaluation of ice milk supplemented with germinated Fenugreek blended in permeate (GFBP treatments).Over all, the data revealed that ice milk containing 2 and $4 \%$ GFBP got high scores for flavour and melting quality in all treatments compared to $6 \%$. Also, ice milk made at these ratios gained the total scores almost close to the control treatments. Generally, adding Cacao or_Nescafe to ice milk supplemented with GFBP improved the flavor and body texture and gained higher acceptable scores than Vanilla. These results indicated that good quality ice milk can be made by supplementing with GFBP.

Table 8. Sensory evaluation of ice milk supplemented with different levels of GFBP.

\begin{tabular}{|c|c|c|c|c|c|c|c|c|c|c|c|c|}
\hline \multirow{2}{*}{ Property } & \multicolumn{4}{|c|}{ Vanilla treatments } & \multicolumn{4}{|c|}{ Cacao treatments } & \multicolumn{4}{|c|}{ Nescafe treatments } \\
\hline & Control & $2 \%$ & $4 \%$ & $6 \%$ & Control & $2 \%$ & $4 \%$ & $6 \%$ & Control & $2 \%$ & $4 \%$ & $6 \%$ \\
\hline Flavour $(50)$ & 45 & 44 & 43 & 41 & 47 & 46 & 47 & 44 & 48 & 47 & 48 & 45 \\
\hline $\begin{array}{l}\text { Body \& Texture } \\
(40)\end{array}$ & 36 & 35 & 35 & 32 & 38 & 37 & 36 & 34 & 38 & 37 & 36 & 35 \\
\hline Melting Quality (10) & 9 & 7 & 8 & 6 & 8 & 7 & 7 & 6 & 7 & 7 & 6 & 6 \\
\hline Total (100) & 90 & 86 & 86 & 79 & 93 & 90 & 90 & 84 & 93 & 91 & 90 & 86 \\
\hline
\end{tabular}

\section{Care, concern and safety in Fenugreek use:}

Beside the beneficial uses and application of Fenugreek; food safety is an important issue and is crucial nowadays because people are very much conscious for their health. Therefore, one should be aware of the fact that how much, in what way, at what time, and in which condition, Fenugreek should be used. Diabetic patients must avoid the use of Fenugreek along with therapeutic medication because it could interfere with the absorption of the therapies that control blood sugar. Also it should not be consumed in excess amount because it has high content of fiber which may cause problem with digestion (Narsaial et al., 2011).

\section{Conclusion}

It could be concluded that, germinated Fenugreek blended in permeate (GFBP) is a good source for 
vitamins and minerals in functional making ice milk and it improves the quality and nutritional value.

\section{References}

AOAC Association of official analytical Chemists (1991). Official; method of Analysis.16 th $\mathrm{ed}$. Vol. N. AOAC official 92:111 Arlington, VA: Association of Official Analytical Chemists.

AOAC (2007) Official; methods of Analysis (18 ${ }^{\text {th }}$ Ed.), Chapter 33,pp.10, 70-72 chapter 45, pp. 101, Association of Official Analytical Chemists Washington, D.C., USA.

Arbuckle W. S. (1986). Ice cream. Third Ed. Avi. Publishing Co. Inc. Westport,

Bailey J.L. (1967). Techniques in Protein Chemistry. Elsevier Publishing Co., London, UK.

Ball G.F.M.(2006).Vitamins in foods, analysis, bioavailability and stability. pp. $(211-219)$ Baoca Raton, FL : CRC Press.

Basch E., Ulbricht C., Kuo G. and Smith M (2003). Therapeutic application of fenugreek. Alt. Med. Rev., 8: 20.

Boilligor S., Goff H.D. and Tharp B.W (2000). Correlation between colloidal properties of ice cream mix and ice cream. International Dairy Journal, 10, 303 - 309.

Brummer Y., Cui W. and Wang Q (2003). Extraction, purification and physicochemical characterization of fenugreek gun. Food hydrocoll. , $17: 229-236$.

Ciftci O.N. and Przyblski R (2011). Characterization of fenugreek (Trigonella foenum-graecum) seed lipids. J. Amr. Oil Chem. Soc., 88: $1603-1610$.

DesideriG.,KwikunbeC.,GrassiD.,NocozionS.,andFerriC.(2012) .Daily Cacao flavanol consumption improve cogenitive function in older adults online at the http://hyper.ahajournals.org/.

Doshi M., Mirza A., Umarji B. and Karambelkar R (2012). Effect of Trigonella foenum-graecum (Fenugreek / Methi) on hemoglobin levels in females of child bearing age. Biomedical Research, 23 (1): 47 - 50.

Dreux C (1977). I Selected method, Analysis of human serum assay of iron II.

Method using bathophenanthroline.Se-Iron II( bathophenanthroline). Ann. Biol. Clin. 35: 275.

Ekinci R. and Kadakal C. (2005).Determination of seven water soluble vitamin in

tarahana, a traditional Turkish cereal food, by HighPerformance Liquid Chromatography. Acta Chromatographica, 15: 289-297.

El Atawy Z.A., Mohamed, L.|M. and Mostafa E.L (2001). Dietetic yoghurt enriched with fenugreek. Egypt. J. Biomed. Sci., vol. 8, 96 - 103.

EImnan A., Balgces A. and Mangara, J.L (2012). Effect of Fenugreek (Trigonella foenm greacum) seed dietary levels on lipid profile and body weight gain of Rats. Pakistan J. of Nutrition 11 (11): 1004-1008.

El-Etriby H.M (1997). Viscosity and $\mathrm{pH}$ of milk as affected by added stabilizers and mineral salts. Egyptian J. dairy Sci., 25: 55 - 63.

El-Merzabani M.M., El-Aaser A.A. and Zakhary N.I (1977). A New method for Determination of inorganic phosphorus in serum Deproteinization. J. Clin. Chem. Clin. Biochem. 15: 715 - 718.

FAO / WHO(1985). Energy and protein requirement. Geneva report of a joint FAO/WHO/ UNU expert Consultation. WHO. Technical report Series No. 724.

FAO/WHO. (1973). Report of FAO/WHO Expert committee on energy and protein requirements. Tech. Report Series 522. World Health Org. Rome.

Food and Drug Administration (1994). International, Arlington,VA,U.S.A.

Gholamali A.J., Maleki M., Motadayen, MH and Sirus, S. (2005). Effect of

Fenugreek, Onion and garlic on blood glucose and histopathology of pancreas of alloxan-induced diabetic rats. Indian J. of Medical Sciences, 59, $64-69$.

Ginder M. and King I.D (1972). Chemical method for determination of calcium in serum . Am. J. Clin. Path. 58: 376.

Giese J.(1996). Fats, oils and fat replacers. Food Technol., 51: 60 .

Hattem H. EI, Elham H. Abou el Enin I. and Mehanna N.M.(2011). Utilization of

milk permeate in the manufacture of sports drinks. J. of Brewing and Distilling vol. 2 (2): 23-27.

Hayakawa R. and Jap J.(1961).Estimation of zinc.Toxic Environ. Health, 8,14 - 18.

Hegazi N.A., Abo El Einen, K.A.M. and ElNawawy, M.A. (2009). Production of low calories highly antioxidant thirst-quenching fruit beverage using milk permeate. J. of Biological Chemistry \& Environmental Sci., 4 (1), 857- 868.

Hooda S and Jood S.(2003). Effect of soaking and germination on nutrient and anti nutrient contents of fenugreek. J. Biochemistry, 27, 165- 176.

Ibrahim S.A., El Dairy S.y. and Fikry Sh, A. (1994). The keeping quality of low calorie butter made with adding kareish cheese of sodium caseinate. Egyptian J. Dairy Sci., 22:47.

Isikli ND. and Karababa E. (2005). Rheological fenugreek paste (cemen). J. Food Eng. 69: 185 190.

Jani R., Udipi SA., and Ghugre PS.(2009). Mineral content of complementary foods Indian. J. Pediatr 76; $37-44$.

Joomla (2009). http:// www.medspice.com. Cited from Ziwar, J., B.(2009). Estimation

of Lipid compostion in Fenugreek seed by GC/MS.

Kaul J. and Mathur B. (1982). Development and assessment of unfermented ice cream 
containing Lactobacillus acidophilus .Indian J. Dairy Sci.35:3.

Kosikowski F. V (1982). Cheese and fermented milk foods. Edwards Brothers, Inc. Michigan, U.S.A.

Leela NK. and Shafeekh KM (2008). Fenugreek chemistry of spices.CAB International, Pondicherry, India.

Marshall R.T. and Arbukle W.S (1996). Ice Cream, Fifth Edition. Chapman and Hall. Int.Thomson Pub.

Marshall R.T., Goff HD. and Hartel R.W (2003). In ice cream (6 Ed), pp. 11-355. Kluwer Academic plenum publishers. London, USA.

Meghwal M. and Goswami TK (2012). A review the functional properties, nutritional content, medicinal utilization and potential application of fenugreek .J. Food Process Technol., 3: 9, 1 - 10.

Narsaial K., Jhasni Bihardwaj R., Sharma R. and Kumar R (2011). Optical biosensors for food quality, and safety assurance: a review .J. Food Sci. Technology 11: 427 - 439.

Nasri NAE. and Tinay AHE (2007). Functional properties of fenugreek (Trigonella foenum graecum) protein concentrate. Food Chem., 103: $582-589$.

Seppanen CM., Song Q. and Csallany AS (2010). The antioxidant functions of tocopherol and tocotrienol homologues in oils, fats and food systems. J. Am oil Chem. SOC. 87: 469-481.
Sharma R. D, Raghuram T.C. and Rao N.S (1990). Effect of fenugreek seeds on blood glucose and serum lipids in type I diabetes. Eur. J. Clin. Nutr ; 44:301-306.

Soukoulis C., Lebesi D. and Tzia C (2009). Enrichment of ice cream with dietary fiber: Effect on rheological properties, ice crystallization and glass transition phenomena. Food Chem., 115:665.

Srinivasan K (2006). Fenugreek (Trigonella foenum graecum). A review of health beneficial physical effects. Food Reviews International 22: $203-$ 224.

Teitz N.W. (1983). Clinical Guide to laboratory Tests. W.B.

Wang - Polagranto J.F., Villablanca A.C. and Schrader H.R (2006). Chronic consumption of flavanol-rich Cocoa improves endothelial function. J. Cardiovascular pharmacology, 47, S 177 - S 186.

Wollgast J. and Anklam E (2000). Polyphenols in chocolate: It these contribution to human health. Food Research International , 33, 449 - 459.

Yousef MK., Wang G., Cui SW. and Barbut S (2009). Purification and partial physicochemical characteristic protein free fenugreek gums. Food Hydrocoll, 23: 2049 - 205 